\title{
Pengaruh Proporsi Jumlah Buah Pepaya dan Tepung Tapioka Terhadap Sifat Kimia dan Tingkat Kesukaan Kerupuk yang Dihasilkan
}

\author{
Effect of Proportion of Amount of Papaya and Tapioca Flour on Chemical Properties and \\ Level of Preference of Produced Crackers \\ Anis Syauqi ${ }^{*}$, Fitriani, Ahmad Zamroni \\ Program Studi Teknologi Hasil Perkebunan, Politeknik Pertanian Negeri Samarinda, Indonesia.
}

*Corresponding Author: anissyauqi@yahoo.co.id

\begin{abstract}
Abstrak
Pepaya (Carica papaya L.) merupakan salah satu komoditas buah yang memiliki banyak fungsi dan manfaat, mengandung nutrisi yang baik serta harga yang relatif terjangkau dibandingkan buah lainnya. Pengolahan buah pepaya menjadi kerupuk juga bertujuan untuk meningkatkan nilai ekonomis serta memperpanjang masa simpan dari buah papaya karena buah papaya memiliki masa simpan yang relatif cukup singkat. Tujuan penelitian ini adalah untuk mengetahui sifat kimia (kadar air, kadar abu dan serat kasar) dan tingkat kesukaan panelis terhadap kerupuk buah papaya yang dihasilkan. Penelitian ini menggunakan Rancangan Acak Lengkap (RAL) dengan Perlakuan yang dilakukan pada penelitian ini ada pada komposisi perbandingan antara tepung tapioka dengan buah pepaya. Pada P1 tepung tapioka sebanyak 560 gram dan buah pepaya sebanyak 140 gram, pada P2 tepung tapioka sebanyak 490 gram dan buah pepaya sebanyak 210 gram, pada P3 tepung tapioka sebanyak 420 gram dan buah pepaya 280 gram, dan pada P4 tepung tapioka sebanyak $350 \mathrm{gram}$ dan buah pepaya 350 gram. Melakukan 3 kali pengulangan, maka banyaknya formula pada penelitian ini berjumlah 12 sampel percobaan. Berdasarkan hasil penelitian menunjukkan bahwa hasil uji kadar air tertinggi pada perlakuan P4 dengan nilai rata-rata $9,75 \%$. Kadar abu yang tertinggi pada perlakuan $\mathrm{P} 4$ dengan nilai rata-rata 2,57\%. Kadar serat kasar tertinggi pada perlakuan P4 dengan nilai rata-rata $6,85 \%$. Nilai tertinggi organoleptik warna pada perlakuan P2 dengan nilai 3,77 pada skala (suka). Nilai tertinggi organoleptik aroma pada perlakuan P2 dengan nilai mencapai 3,59 pada skala (suka). Nilai tertinggi organoleptik rasa pada perlakuan P2 dengan nilai 3,67 pada skala (suka). Dan nilai tertinggi pada organoleptik tekstur pada perlakuan P3 dengan nilai mencapai 3,57 pada skala (suka).
\end{abstract}

Kata kunci : Buah pepaya, Kerupuk, Kadar abu, Kadar air.kadar serat kasar, uji organoleptik

\begin{abstract}
Papaya (Carica papaya L.) is a fruit commodity that has many functions and benefits, contains good nutrition, and the price is relatively affordable compared to other fruits. Processing papaya fruit into crackers also aims to increase the economic value and extend the shelf life of papaya fruit because papaya fruit has a relatively short shelf life. The purpose of this study was to determine the chemical properties (moisture content, ash content and crude fiber) and the panelists' preference for papaya crackers. This study used a completely randomized design (CRD) with the treatment carried out in this study in the composition of the comparison between tapioca flour and papaya fruit. At $P 1$ tapioca flour as much as 560 grams and papaya fruit as much as 140 grams, at $P 2$ tapioca flour as much as 490 grams and papaya fruit as much as 210 grams, at $P 3$ tapioca flour as much as 420 grams and papaya fruit $280 \mathrm{grams}$, and at $P 4$ tapioca flour as much as 350 grams and papaya fruit 350 grams. Doing 3 repetitions, the number of formulas in this study amounted to 12 experimental samples. Based on the results of the study, it was shown that the highest water content test results were in the P4 treatment with an average value of $9.75 \%$. The highest ash content was in the P4 treatment with an average value of $2.57 \%$. The highest crude fiber content was in the P4 treatment with an average value of $6.85 \%$. The highest value of color organoleptic was in the $P 2$ treatment with a value of 3.77 on the scale (like). The highest value of organoleptic aroma was in the P2 treatment with a value reaching 3.59 on the (like) scale. The highest value of taste organoleptic was in the P2 treatment with a value of 3.67 on the scale (like). And the highest score on the texture organoleptic was in the P3 treatment with a value reaching 3.57 on the (like) scale.
\end{abstract}

Keywords: Papaya fruit, crackers, ash content, water content, crude fiber content, organoleptic test. 


\section{PENDAHULUAN}

Pepaya (Carica papaya L.) merupakan salah satu komoditas buah yang memiliki banyak fungsi dan manfaat, mengandung nutrisi yang baik, harga yang relatif terjangkau dibandingkan buah lainnya. Pepaya merupakan tanaman unggulan yang sangat berpotensi untuk lebih dikembangkan di Indonesia. Pengembangan pepaya memerlukan ketersediaan benih secara berkesinambungan, sebab peremajaan tanaman selalu diperlukan untuk mendapatkan produksi yang baik. Pepaya selain untuk kepentingan komersial, mengharuskan penanganan benih pepaya yang sangat penting untuk pengolaan plasma nutfa (Suketi dan Sujiprihati 2009).

Kerupuk merupakan suatu jenis makanan kecil yang sudah lama dikenal oleh sebagai masyarakat Indonesia. Kerupuk dapat dikonsumsi sebagai makanan selingan maupun sebagai varian dalam lauk pauk. Pada umumnya kerupuk dikonsumsi sebagai makanan tambahan untuk lauk pauk atau sebagai makanan kecil salah satu faktor utama yang menentukan mutu kerupuk adalah kerenyahannya, semua konsumen menyukai kerupuk yang renyah. Kebanyakan masyarakat mengolah buah pepaya menjadi sayur dan salad buah. Pengolahan buah pepaya menjadi kerupuk juga bertujuan untuk meningkatkan nilai ekonomis serta memperpanjang masa simpan dari buah papaya karena buah papaya memiliki masa simpan yang relatif cukup singkat.Tetapi belum diketahui berapa komposisi buah papaya yang perlu ditambahkan sebagai bahan subtitusi dalam pengolahan kerupuk, sehingga perlu dilakukan penelitian ini.

\section{METODE PENELITIAN}

\section{A. Waktu Dan Tempat}

Penelitian ini dilakukan pada bulan Mei - September 2021 berlokasi di Laboratorium Pengolahan dan Laboratorium Kimia Analitik, Program Studi Teknologi Hasil Perkebunan, Jurusan Teknologi Pertanian, Politeknik Pertanian Negeri Smarinda.

\section{B. Alat Dan Bahan}

1. Alat

Alat yang digunakan adalah timbangan analitik, blender, kain saring, pisau, talenan, baskom, tirisan, tampah, solet, parutan, sendok, plastik, corong, panci pengukus, kompor dan gas, gelas ukur, hot plate, spatula, labu ukur, cawan porselin, cawan petri, pipet, erlemeyer, corong, tabung reaksi, oven, desikator,kertas saring, gegep, dan tanur.

\section{Bahan}

Bahan yang digunakan adalah buah pepaya, tepung tapioka, bawang putih, ketumbar bubuk, garam dan air, larutan $\mathrm{H}_{2} \mathrm{SO}_{4} 1,25 \%$, $\mathrm{NaOH} 3,25 \%$, etanol $96 \%$, dan aquades.

\section{Rancangan Penelitian}

Rancangan Penelitian yang digunakan dalam penelitian ini adalah Rancangan Acak Lengkap (RAL). Pada penelitian ini memiliki 4 perlakuan Dengan perbandingan tepung tapioka dan buah papaya yang dilambangkan $\mathrm{P} 1=80 \%: 20 \%, \mathrm{P} 2=70 \%: 30 \%, \mathrm{P} 3=60 \%$ : $40 \%, \mathrm{P} 4=50 \%: 50 \%$, dengan masingmasing perlakuan diulangan sebanyak 3 kali.

Parameter yang diuji pada penelitian ini adalah kadar air, kadar abu, serat kasar, dan organoleptik.

\section{Prosedur Pembuatan Kerupuk}

1. Alat dan bahan disiapkan

2. Buah pepaya dikupas dan dibersihkan dari biji kemudian dicuci bersih.

3. Pemotongan buah pepaya menjadi empat bagian kemudian diparut.

4. Diperas buah pepaya menggunakan kain saring bersih.

5. Tepung tapioka dan buah pepaya ditimbang sesuai dengan formulasi resep.

6. Kemudian bawang putih dibersihkan dan ditimbang sebanyak 25 gram kemudian dihancurkan dengan menggunakan diblender.

7. Bumbu seperti ketumbar bubuk, garam dan penyedap rasa ditimbang.

8. Dicampurkan antara tepung tapioka dengan buah pepaya yang sudah diperas beserta bumbu tambahan di dalam baskom hingga homogen.

9. Adonan kerupuk dimasukkan ke dalam plastik untuk direbus selama 45 menit.

10. Diangkat adonan kerupuk dari panci kemudian didinginkan.

11. Adonan kerupuk didiamkan selama semalaman. 
12. Kemudian dijemur selama 1 jam

13. Setelah itu adonan kerupuk diiris tipis.

14. Potongan kerupuk disusun di atas tampah dan dijemur dibawah sinar matahari selama 4 hari.

15. Kerupuk kering disimpan di dalam plastik.

16. Kemudian kerupuk buah pepaya siap digoreng dan diuji.

\section{E. Prosedur Analisa}

1. Kadar Air Metode Oven (BPMSP, 2019)

Menurut BSN, 1992 dalam BPMSP, 2019 menyatakan bahwa prinsip pengujian kadar air adalah kehilangan bobot pada pemanasan $105^{\circ} \mathrm{C}$ dianggap sebagai kadar air yang terdapat pada sampel. Adapun cara untuk menentukan kadar air metode oven adalah sebagai berikut:

a. Ditimbang sampel dengan berat $1-2$ gram pada sebuah botol timbang bertutup yang sudah diketahui bobotnya. Untuk sampel berupa cairan, botol timbang dilengkapi dengan pengaduk dan pasir kwarsa/ kertas saring berlipat.

b. Sampel dikeringkan pada oven suhu $105^{\circ} \mathrm{C}$ selama 3 jam.

c. Dinginkan sampel dalam desikator.

d. Sampel ditimbang, ulangi langkah ini hingga diperoleh bobot tetap dimana selisih yang diperoleh maksimal 0,0002 gram.

$$
\text { Kadar air }=\frac{(\mathrm{W} 1+\mathrm{W} 2)-\mathrm{W} 3}{\mathrm{~W} 2} \times 100 \%
$$

Keterangan:

W1 $=$ Berat cawan kosong (gram)

W2 = Berat sampel (gram)

W3 = Berat cawan dan sampel setelah oven (gram).

\section{Kadar Abu (BPMSP, 2019)}

a. Ditimbang 2-3 gram sampel ke dalam sebuah cawan porselen (atau platina) yang telah diketahui bobotnya, untuk sampel cairan uapkan di atas penangas air sampai kering.

b. Sampel diarangkan di atas nyala pembakar, lalu diabukan dalam tanur listrik pada suhu $550^{\circ} \mathrm{C}-600^{\circ} \mathrm{C}$ sampai pengabuan sempurna (sesekali pintu tanur dibuka sedikit agar oksigen bisa masuk).

c. Dinginkan dalam desikator, lalu timbang hingga bobot tetap.
Kadar abu $=\frac{\mathrm{W} 1-\mathrm{W} 2}{\mathrm{~W}} \times 100 \%$

Keterangan:

$\mathrm{W}$ = Bobot cuplikan (gram)

$\mathrm{W} 1$ = Bobot contoh + cawan sesudah diabukan (gram)

W2 = Bobot cawan kosong (gram)

3. Serat Kasar (Korompot, 2018)

a. Ditimbang 1-2 gram sampel

b. Dihilangkan lemaknya dengan cara ekstrasi soxhletasi atau dengan cara mengadukan

c. Tuangkan sampel dalam pelarut organik sebanyak 3 kali

d. Kemudian dikeringkan dan dimasukan kedalam erlenmeyer $500 \mathrm{ml}$

e. Ditambahkan $50 \mathrm{ml}$ larutan $\mathrm{H}_{2} \mathrm{SO}_{4} 1,25 \%$

f. Kemudian dididihkan selama 30 menit dengan menggunakan pendingin tegak sebanyak $50 \quad \mathrm{ml} \quad \mathrm{NaOH} \quad 3,25 \%$ ditambahkan

g. Kemudian dididihkan lagi selama 30 menit. Dalam keadaan panas disaring dengan corong yang berisi kertas saring yang telah dikeringkan dan diketahui beratnya (W1).

h. Endapan yang terdapat pada kertas saring dicuci berturut-turut dengan $\mathrm{H}_{2} \mathrm{SO}_{4} 1,25 \%$ panas, Aquades panas dan etanol $96 \%$.

i. Kertas saring diangkat dan dimasukan ke kotak timbangan (W2) yang telah diketahui beratnya

j. Kemudian dikeringkan pada suhu $105^{\circ} \mathrm{C}$ didinginkan dan ditimbang sampai bobot tetap (W3). Bila ternyata berat serat kasar lebih dari $1 \%$ diabukan kertas saring beserta isinya, ditimbang sampai berat tetap dengan rumus:

$$
\text { serat } k \text { asar }=\frac{(\mathrm{W} 3-\mathrm{W} 2)-\mathrm{W} 1}{\text { berat sampel }} \times 100 \%
$$

\section{Uji Organoleptik}

Uji organoleptik dilakukan menggunakan metode Setianingsih dkk. (2010) dimana parameter yang diuji meliputi warna, rasa, aroma dan tekstur. 


\section{HASIL DAN PEMBAHASAN}

\section{A. Uji Kadar Air}

Tujuan pada uji kadar air adalah untuk mengetahui jumlah air yang terdapat dalam produk akhir yang dihasilkan. Jika kandungan air pada bahan kering tersebut mengalami sedikit kenaikan maka dapat mengakibatkan kerusakan, baik akibat reaksi kimiawi maupun pertumbuhan mikroba pembusuk (Nadia dkk., 2014). Semakin banyak kadar air yang terkandung dalam suatu bahan maka akan mengakibatkan penurunan kualitas terhadap produk yang akan dihasilkan.

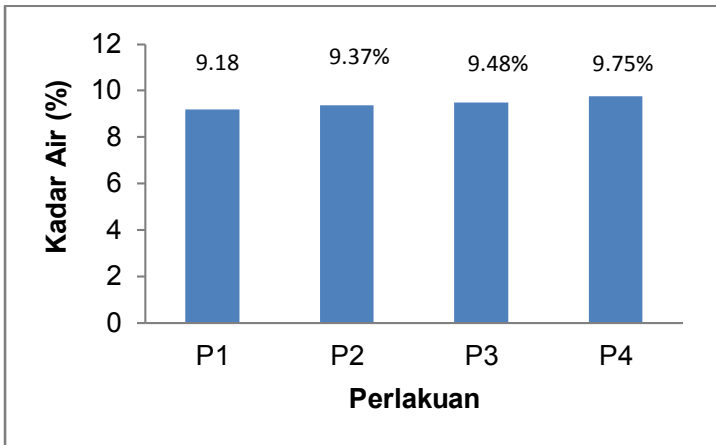

Gambar 1. Grafik Nilai Rata-rata Uji Kadar Air. Sumber: Data primer, 2021

Hasil pada gambar 2 menunjukan menunjuk kan nilai rata-rata kadar air dari kerupuk buah pepaya diperoleh kadar air yang tertinggi pada perlakuan P4 dengan nilai rata-rata $9.75 \%$ dengan $50 \%$ tepung tapioka dan $50 \%$ buah papaya. Sedangkan jumlah rata-rata terendah terdapat pada perlakuan $\mathrm{P} 1$ dengan nilai $9.18 \%$ dengan tepung tapioka $80 \%$ dan buah pepaya $20 \%$. Sehingga dapat disimpulkan bahwa semakin banyak penambahan buah pepaya dan semakin sedikit tepung tapioka pada kerupuk mengakibatkan kadar air kerupuk buah pepaya meningkat.

Faktor bertambahnya kadar air pada kerupuk buah pepaya disebabkan penambahan buah papaya. Dengan waktu pengeringan yang sama menyebabkan semakin banyak penambahan buah pepaya menyebabkan kadar air akan semakin tinggi. Kadar air yang tinggi juga dapat disebabkan oleh jumlah protein yang ada pada buah pepaya dikarenakan protein adalah zat kimia yang dapat menyerap air sehingga kadar air akan lebih sulit berkurang. Dari hasil analisa kadar air dapat diketahui setiap penambahan buah pepaya akan mengakibatkan kenaikan kadar air kerupuk. Hal ini disebabkan karena buah pepaya memiliki kandungan air. Sehingga ketika buah pepaya ditambahkan akan mengakibatkan kenaikan kadar air pada kerupuk. Kenaikan kadar air pada kerupuk ini berpengaruh terhadap tekstur dan daya kembang kerupuk saat digoreng.

Data tersebut kemudian dianalisa menggunakan sidik ragam untuk mengetahui apakah perlakuan dengan penambahan tepung tapioka dan buah pepaya berpengaruh signifikan atau tidak signifikan terhadap kandungan kadar air pada kerupuk buah pepaya. sebagai berikut:

Tabel 6. Analisis sidik ragam kadar air

\begin{tabular}{ccccccc}
\hline $\begin{array}{c}\text { Sumber } \\
\text { Keragaman }\end{array}$ & $\begin{array}{c}\text { Derajat } \\
\text { Bebas }\end{array}$ & JK & KT & F Hit & \multicolumn{2}{c}{ F Tabel } \\
\cline { 6 - 7 } Perlakuan & 3 & 0,513 & 0,17 & $0,85^{\text {th }}$ & 4,07 & 7,59 \\
Galat & 8 & 1,612 & 0,20 & & & \\
\hline Total & 11 & 2,125 & & & & \\
\hline
\end{tabular}

Sumber : Data primer setelah diolah, 2021

Keterangan : ${ }^{\text {tn }}$ ) tidak berbeda nyata

Berdasarkan analisa sidik ragam kadar air menyatakan bahwa $F$ hitung $(0,85)$ lebih kecil dari $\mathrm{F}$ tabel $5 \%(4,07)$ dan $\mathrm{F}$ tabel $1 \%$ $(7,59)$. Hasil analisa sidik ragam ini menunjukan bahwa penambahan buah pepaya tidak berpengaruh nyata terhadap kadar air kerupuk buah pepaya.

\section{B. Uji Kadar Abu}

Kadar abu merupakan zat organik sisa suatu pembakaran zat organik dalam bahan pangan. Bahan pangan terdiri dari $96 \%$ bahan organik dan air, sedangkan sisanya merupakan unsur-unsur mineral. Penentuan kadar abu dapat ditentukan dengan tujuan, antara lain untuk menentukan baik atau 
tidaknya suatu pengolahan, mengetahui jenis bahan yang digunakan dan sebagai penentu nilai gizi suatu bahan makanan (Desi, 2017). Hasil analisa rata-rata kadar abu kerupuk buah pepaya dari keempat perlakuan dengan tiga kali ulangan, ditunjukan pada grafik Gambar 3

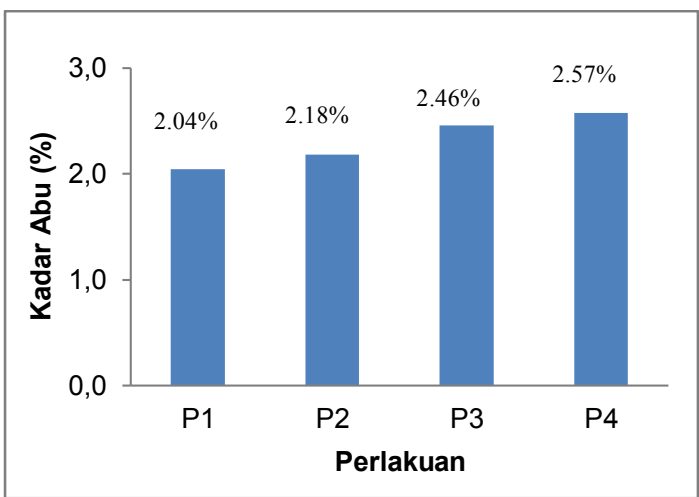

Gambar 3. Grafik Nilai Rata-rata Uji Kadar Abu

Berdasarkan dari gambar diatas dapat dilihat pada perlakuan P4 memberikan hasil kadar abu tertinggi dengan nilai rata-rata yaitu $2.57 \%$ dengan tepung tapioka $50 \%$ dan buah pepaya $50 \%$. Sedangkan P1 memberikan hasil abu yang terendah yaitu $2.04 \%$ dengan tepung tapioka $80 \%$ dan buah pepaya $20 \%$. Hal ini disebabkan karena pada perlakuan P4 lebih banyak mengandung mineral. Sehingga dapat disimpulkan bahwa semakin banyak penambahan buah pepaya pada kerupuk mengakibatkan kadar abu kerupuk buah pepaya meningkat. Semakin tinggi kadar abu pada suatu produk maka semakin tinggi kandungan mineral tersebut, sedangkan semakin rendah kadar abu pada produk maka semakin rendah kandungan mineral pada produk tersebut dan dengan tingginya mineral dalam bahan pangan tidak dapat mempengaruh nilai gizi pada suatu produk.

Data tersebut kemudian dianalisa menggunakan sidik ragam untuk mengetahui apakah perlakuan penambahan berpengaruh signifikan atau tidak signifikan terhadap kandungan kadar abu pada kerupuk buah pepaya.

Berdasarkan analisa sidik ragam kadar abu menyatakan bahwa $F$ hitung $(0,64)$ lebih kecil dari $F$ tabel $(4,07)$. Hasil analisa sidik ragam ini menunjukan bahwa penambahan buah pepaya tidak berpengaruh nyata terhadap kadar air kerupuk.

Tabel 7. Analisis sidik ragam kadar abu

\begin{tabular}{ccccccc}
\hline $\begin{array}{c}\text { Sumber } \\
\text { Keragaman }\end{array}$ & $\begin{array}{c}\text { Derajat } \\
\text { Bebas }\end{array}$ & JK & KT & F Hit & \multicolumn{2}{c}{ F Tabel } \\
\cline { 5 - 7 } Perlakuan & 3 & 0,54 & 0,18 & $0,71^{\text {th }}$ & 4,07 & 7,59 \\
Galat & 8 & 1,99 & 0,25 & & & \\
\hline Total & 11 & 2,53 & & & & \\
\hline \multicolumn{7}{c}{ Sumber : Data primer setelah diolah, 2021 }
\end{tabular}

\section{B. Serat Kasar}

Pada pengujian serat pada kerupuk buah pepaya dilakukan uji sampel yaitu kerupuk mentah, tujuan dari pengujian ini yaitu untuk mengetahui kandungan serat yang ada pada kerupuk buah pepaya.

Adapun penyajian data dalam bentuk grafik, dapat dilihat pada gambar berikut.

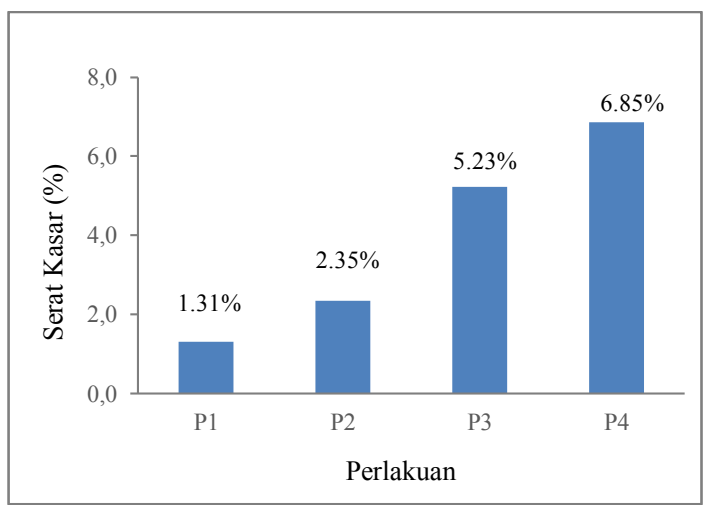

Gambar 4. Grafik Rata-rata Uji Serat Kasar Kerupuk Pepaya 
Dari gambar diatas dapat kita ketahui bahwa hasil uji serat kasar tertinggi pada perlakuan $\mathrm{P} 4$ dengan tepung tepung tapioka $50 \%$ dan buah pepaya $50 \%$ dengan nilai rata-rata yaitu $6.85 \%$. Sedangkan jumlah rata - rata terendah pada perlakuan P1 dengan nilai $1.31 \%$ dengan tepung tapioka $80 \%$ dan buah pepaya $20 \%$. Berdasarkan hasil analisa mulai dari P1 hingga P4 dapat disimpulan bahwa penambahan buah pepaya berpengaruh pada pada serat kasar yang dihasilkan.

Data tersebut kemudian dianalisa menggunakan sidik ragam untuk mengetahui apakah perlakuan penambahan berpengaruh signifikan atau tidak signifikan terhadap kandungan kadar abu pada kerupuk buah pepaya.

Tabel 8. Analisis sidik ragam serat kasar

\begin{tabular}{ccccccc}
\hline $\begin{array}{c}\text { Sumber } \\
\text { Keragaman }\end{array}$ & $\begin{array}{c}\text { Derajat } \\
\text { Bebas }\end{array}$ & JK & KT & F Hit & \multicolumn{2}{c}{ F Tabel } \\
\cline { 5 - 7 } Perlakuan & 3 & 1,15 & 0,38 & $36,66^{* *}$ & 4,06 & 7,59 \\
Galat & 8 & 0,08 & 0,01 & & & \\
\hline Total & 11 & 1,23 & & \\
\hline \multicolumn{7}{c}{ Sumber: Data primer setelah diolah, 2021 }
\end{tabular}

Hasil analisa sidik ragam memperlihatkan bahwa perlakuan $\mathrm{F}$ hitung lebih besar dari $\mathrm{F}$ tabel $5 \%$ dan $\mathrm{F}$ tabel $1 \%$ yang berarti berbeda sangat nyata. Maka semakin banyak buah pepaya yang ditambahkan semakin tinggi serat kasar yang dihasil dari hasil analisa sidik ragam dapat dilihat penambahan buah papaya yang berbeda sangat nyata.

\section{Uji Organoleptik}

\section{Warna}

Berdasarkan uji organoleptik faktor warna sangat menentukan penilaian bahan pangan sebelum faktor-faktor lain dipertimbangkan secara visual dikarenakan warna berperan penting dalam proses penerimaan konsumen terhadap suatu produk pangan. Hal yang pertama dilihat oleh seseorang apabila hendak memilih suatu pangan tertentu, yaitu dengan mengamati tampilan warna. Selain itu, warna juga dapat menjadi pemberi informasi terhadap perubahan kimia yang terjadi pada sebuah makanan. Hasil penelitian terhadap rata-rata tingkat kesukaan panelis terhadap warna kerupuk buah pepaya dapat dilihat pada gambar grafik 5 .

Adapun penyajian data dalam bentuk grafik, dapat dilihat pada gambar berikut :

Berdasarkan hasil uji organoleptik, warna Berdasarkan gambar 5 menunjukkan bahwa hasil dari pengujian organoleptik warna pada kerupuk buah pepaya yaitu memiliki nilai rata-rata berkisar antara 2,99 sampai dengan 3,61 . Hal ini berarti warna kerupuk ini masuk pada range skala agak suka hingga suka. Semakin tinggi konsentrasi penambahan buah pepaya mengakibatkan penurunan tingkat penerimaan panelis terhadap warna kerupuk. Hal ini disebabkan semakin banyak penambahan buah pepaya maka warna yang dihasilkan akan semakin cokelat. Sehingga kerupuk buah pepaya kurang diminati oleh panelis.

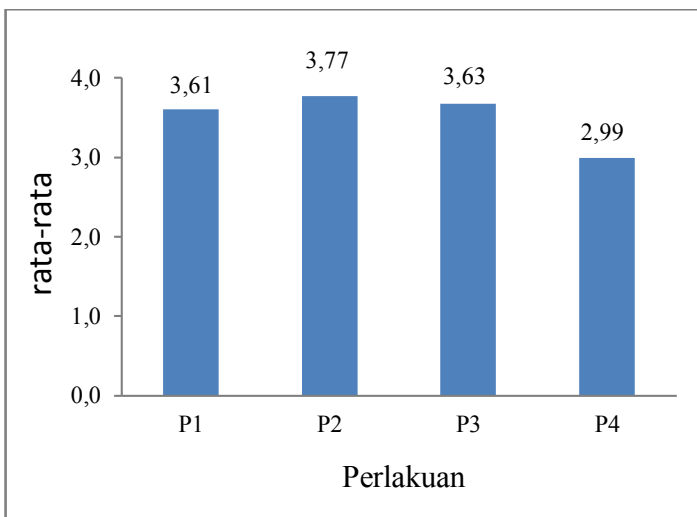

Gambar 5. Grafik Rata-rata Uji Organoleptik Warna Kerupuk Buah Pepaya

Faktor yang menyebabkan bahan pangan mengalami perubahan warna akibat pengaruh warna panas terhadap gula dan tepung yang ditambahkan atau terdapat secara alami pada buah itu sendiri yang menyebabkan terjadi reaksi pencoklatan enzimatik (Winarno, 2004). 
Tabel 9. Analisis sidik ragam organoleptik warna

\begin{tabular}{|c|c|c|c|c|c|c|}
\hline \multirow{2}{*}{$\begin{array}{c}\text { Sumber } \\
\text { Keragaman }\end{array}$} & \multirow{2}{*}{$\begin{array}{l}\text { Derajat } \\
\text { Bebas }\end{array}$} & \multirow{2}{*}{ JK } & \multirow{2}{*}{$K T$} & \multirow{2}{*}{ F Hit } & \multicolumn{2}{|c|}{ F Tabel } \\
\hline & & & & & $5 \%$ & $1 \%$ \\
\hline Perlakuan & 3 & 1,137 & 0,37 & $2,57^{\mathrm{tn}}$ & 4,06 & 7,59 \\
\hline Galat & 8 & 1,179 & 0,14 & & & \\
\hline Total & 11 & 2,317 & & & & \\
\hline
\end{tabular}

Hasil analisa sidik ragam memperlihatkan bahwa $\mathrm{F}$ hitung lebih kecil dari $\mathrm{F}$ tabel $5 \%$ dan $\mathrm{F}$ tabel $1 \%$ yang berarti tidak berbeda nyata.

\section{Aroma}

Aroma yang timbul pada kerupuk buah pepaya ini didominasi oleh aroma rempah. Hal ini dikarenakan rempah berfungsi sebagai pemberi aroma dan rasa pada kerupuk buah pepaya. Hasil penelitian terhadap rata-rata tingkat kesukaan panelis terhadap aroma kerupuk buah pepaya dapat dilihat pada gambar grafik 6 .

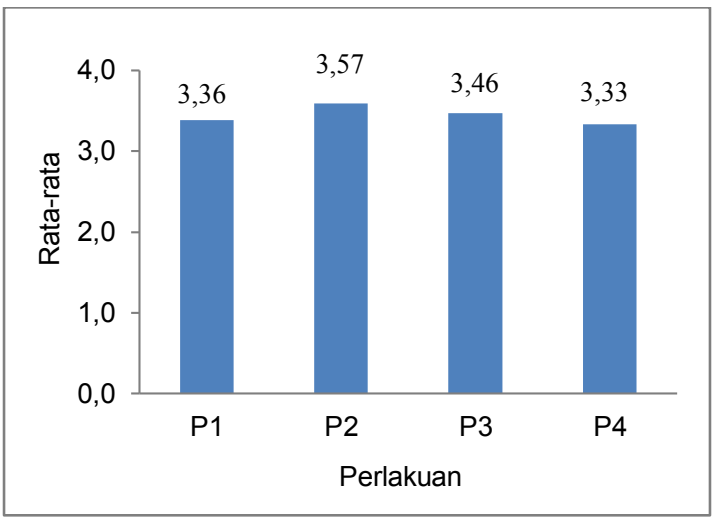

Gambar 6. Grafik Rata-rata Uji Organoleptik Aroma Kerupuk Buah Pepaya
Berdasarkan hasil uji organoleptik, warna Berdasarkan gambar 6 menunjukkan bahwa hasil dari pengujian organoleptik aroma pada kerupuk buah pepaya yaitu memiliki nilai rata-rata berkisar antara 3,33 sampai dengan 3,59. Hal ini berarti aroma kerupuk ini masuk pada range skala agak suka hingga suka.

Jumlah rata-rata tertinggi pada aroma ditunjukan pada perlakuan P2 yaitu dengan penambahan tepung tapioka $70 \%$ dan buah pepaya $30 \%$ dengan hasil rata-rata yaitu 3,59 pada skala suka. Sedangkan jumlah rata-rata terendah pada pengujian organoleptik aroma ini terdapat pada perlakuan $\mathrm{P} 4$ yaitu dengan penambahan tepung tapioka $50 \%$ dan buah pepaya $50 \%$ dengan hasil rata-rata sebesar 3,33 pada skala agak suka. Sehingga dapat disimpulkan lebih banyak penambahan buah pepaya mengakibatkan penurunan tingkat kesukaan panelis.

Data tersebut kemudian dianalisa menggunakan sidik ragam untuk mengetahui apakah perlakuan penambahan buah pepaya dan tepung tapioka berpengaruh signifikan atau tidak signifikan terhadap warna pada kerupuk buah pepaya.

Tabel 10. Analisis Sidik Ragam Organoleptik Aroma

\begin{tabular}{|c|c|c|c|c|c|c|}
\hline \multirow{2}{*}{$\begin{array}{c}\text { Sumber } \\
\text { Keragaman }\end{array}$} & \multirow{2}{*}{$\begin{array}{l}\text { Derajat } \\
\text { Bebas }\end{array}$} & \multirow{2}{*}{ JK } & \multirow{2}{*}{$K T$} & \multirow{2}{*}{ F Hit } & \multicolumn{2}{|c|}{ F Tabel } \\
\hline & & & & & $5 \%$ & $1 \%$ \\
\hline Perlakuan & 3 & 0,109 & 0,036 & $1,45^{\mathrm{tn}}$ & 4,06 & 7,59 \\
\hline Galat & 8 & 0,199 & 0,024 & & & \\
\hline Total & 11 & 0,308 & & & & \\
\hline
\end{tabular}


Hasil analisa sidik ragam memperlihatkan bahwa $\mathrm{F}$ hitung lebih kecil dari $\mathrm{F}$ tabel $5 \%$ dan $\mathrm{F}$ tabel $1 \%$ yang berarti tidak berbeda nyata.

\section{Rasa}

Rasa merupakan unsur yang penting dalam menentukan penerimaan konsumen terhadap suatu produk pangan dan merupakan faktor kedua yang mempengaruhi cita rasa makanan setelah penampilan makanan itu sendiri (Utami dkk., 2016). Rasa yang timbul pada kerupuk buah pepaya ini adalah rasa bawang putih. Nilai organoleptik tingkat kesukaan rasa pada kerupuk buah pepaya dapat dilihat pada Gambar 7 .

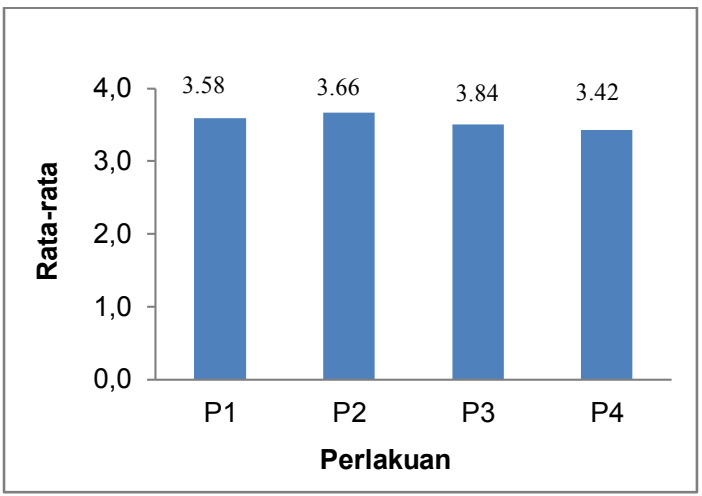

Gambar 7. Grafik Rata-rata Uji Organoleptik Rasa Kerupuk Buah Pepaya
Berdasarkan hasil uji oraganoleptik rasa, menunjukan bahwa tingkat kesukaan panelis tertinggi pada perlakuan P2 dengan penambahan tepung tapioka $70 \%$ dan buah pepaya $30 \%$ dengan nilai rata-rata berkisar antara 3,43 sampai dengan 3,67. Hal ini berarti rasa kerupuk ini masuk pada skala agak suka hingga suka.

Jumlah rata-rata tertinggi pada uji organoleptik rasa ditunjukkan pada perlakuan $\mathrm{P} 2$ yaitu dengan penambahan tepung tapioka $70 \%$ dan buah pepaya $30 \%$ dengan hasil rata-rata sebesar 3,67 pada skala suka. Sedangkan jumlah rata-rata terendah pada pengujian organoleptik rasa ini terdapat pada perlakuan $\mathrm{P} 4$ yaitu dengan penambahan tepung tapioka sebanyak $50 \%$ dan buah pepaya $50 \%$ dengan hasil rata-rata sebesar 3,43 pada skala agak suka. Sehingga dapat disimpulkan bahwa semakin banyak penambahan buah pepaya pada kerupuk mengakibatkan penurunan tingkat kesukaan panelis terhadap rasa kerupuk dikarenakan rasa bawang semakin berkurang.

Data tersebut kemudian dianalisa menggunakan sidik ragam untuk mengetahui apakah perlakuan penambahan buah pepaya dan tepung tapioka berpengaruh signifikan atau tidak signifikan terhadap warna pada kerupuk buah pepaya.

Tabel 11. Analisis Sidik Ragam Organoleptik Rasa

\begin{tabular}{ccccccc}
\hline $\begin{array}{c}\text { Sumber } \\
\text { Keragaman }\end{array}$ & $\begin{array}{c}\text { Derajat } \\
\text { Bebas }\end{array}$ & JK & $K T$ & F Hit & \multicolumn{2}{c}{ F Tabel } \\
\cline { 4 - 7 } & 3 & 0,096 & 0,03 & $0,32^{\text {th }}$ & 4,06 & 7,59 \\
\hline Perlakuan & 8 & 0,778 & 0,09 & & & \\
Galat & 11 & 0,874 & & & & \\
\hline Total & Sumber : Data primer setelah diolah, 2021 \\
& Keterangan: $\left({ }^{\text {tn }}\right)$ berbeda tidak nyata & &
\end{tabular}

Hasil analisa sidik ragam memperlihatkan bahwa $\mathrm{F}$ hitung lebih kecil dari $\mathrm{F}$ tabel $5 \%$ dan $\mathrm{F}$ tabel $1 \%$ yang berarti tidak berbeda nyata.

\section{Tekstur}

Tingkat kesukaan terhadap tekstur pada pembuatan kerupuk buah pepaya diketahui melalui uji organoleptik. Pengujian tekstur pada kerupuk buah pepaya sangat penting dilakukan. Menurut Dewi Kusuma dalam Panti Mukmin (2014), setiap makanan mempunyai tekstur tersendiri tergantung keadaan fisik, ukuran, dan bentuknya.
Penilaian terhadap tekstur dapat berupa kekerasan, elastisitas, kerenyahan dan sebagainya.

Pada penelitian ini tekstur kerupuk dapat dirasakan dengan digigit atau dikunyah. Hasil penelitian terhadap rata-rata tingkat kesukaan panelis terhadap tekstur kerupuk buah pepaya dapat dilihat pada gambar grafik 8. Adapun penyajian data dalam bentuk grafik, dapat dilihat pada gambar berikut. 


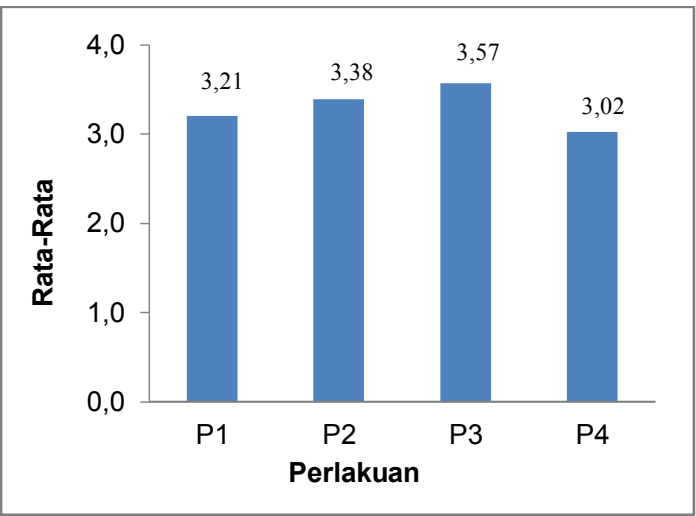

Gambar 8. Grafik Rata-rata Uji Organoleptik Tekstur Kerupuk Buah Pepaya

Berdasarkan hasil uji oraganoleptik Tekstur, menunjukan bahwa tingkat kesukaan panelis tertinggi pada perlakuan P3 dengan penambahan tepung tapioka $60 \%$ dan buah pepaya $40 \%$ dengan nilai rata-rata berkisar antara 3,03 sampai dengan 3,57. Hal ini berarti rasa kerupuk ini masuk pada skala agak suka hingga suka.
Jumlah rata-rata tertinggi pada uji organoleptik tekstur ditunjukkan pada perlakuan P3 yaitu dengan penambahan tepung tapioka $60 \%$ dan buah pepaya $40 \%$ dengan hasil rata-rata yaitu 3,57 pada skala suka. Sedangkan jumlah rata-rata terendah pada pengujian organoleptik rasa ini terdapat pada perlakuan P4 yaitu dengan penambahan tepung tapioka sebanyak $50 \%$ dan buah pepaya $50 \%$ dengan hasil rata-rata sebesar 3,03 pada skala agak suka. Sehingga dapat disimpulkan bahwa semakin banyak penambahan buah pepaya pada kerupuk mengakibatkan penurunan tingkat kesukaan panelis terhadap tekstur kerupuk dikarenakan tekstur kerupuk yang dihasilkan makin keras.

Data tersebut kemudian dianalisa menggunakan sidik ragam untuk mengetahui apakah perlakuan penambahan buah pepaya dan tepung tapioka berpengaruh signifikan atau tidak signifikan terhadap warna pada kerupuk buah pepaya.

Tabel 12. Analisa Sidik Ragam Organoleptik Tekstur

\begin{tabular}{|c|c|c|c|c|c|c|}
\hline \multirow{2}{*}{$\begin{array}{c}\text { Sumber } \\
\text { Keragaman }\end{array}$} & \multirow{2}{*}{$\begin{array}{c}\text { Derajat } \\
\text { Bebas }\end{array}$} & \multirow{2}{*}{ JK } & \multirow{2}{*}{$K T$} & \multirow{2}{*}{ F Hit } & \multicolumn{2}{|c|}{ F Tabel } \\
\hline & & & & & $5 \%$ & $1 \%$ \\
\hline Perlakuan & 3 & 0,493 & 0,16 & $0,93^{\text {tn }}$ & 4,06 & 7,59 \\
\hline Galat & 8 & 1,412 & 0,17 & & & \\
\hline Total & 11 & 1,905 & & & & \\
\hline
\end{tabular}

Dari hasil analisa sidik ragam memperlihatkan bahwa $\mathrm{F}$ hitung 0,93 lebih kecil dari $F$ tabel $5 \%(4,06)$ dan $F$ tabel $1 \%$ $(7,59)$ yang berarti tidak berbeda nyata.

\section{KESIMPULAN DAN SARAN}

\section{A. Kesimpulan}

1. Pembuatan kerupuk dengan penambahan buah pepaya memilliki kandungan kadar air tertinggi pada perlakuan $\mathrm{P} 4$ dengan nilai rata-rata kadar air 9,75\%. Kadar abu tertinggi pada perlakuan $\mathrm{P} 4$ dengan nilai ratarata $2,57 \%$ Dan serat kasar tertinggi pada perlakuan $\mathrm{P} 4$ dengan nilai ratarata $6,85 \%$.

2. Hasil organoleptik terhadap pembuatan kerupuk dengan penambahan buah pepaya memperlihatkan bahwa warna, aroma, rasa, dan tekstur terhadap kesukaan panelis menunjukan angka suka yaitu rata-rata nilai tertinggi warna pada perlakuan $\mathrm{P} 2$ dengan nilai ratarata $3.77 \%$ hal ini disebabkan semakin banyak penambahan buah pepaya maka warna yang dihasilkan akan semkain cokelat, sehingga kerupuk buah pepaya kurang diminati panelis. Kemudian nilai tertinggi aroma pada perlakuan P2 dengan nilai rata-rata $3.59 \%$ sehingga dapat disimpulkan lebih banyak penambahan buah pepaya mengakibatkan penurunan tingkat kesukaan panelis.pada rasa nilai tertinggi pada perlakuan kedua P2 dengan nilai rata-rata $3.67 \%$ dapat disimpulkan bahwa semakin banyak penambahan buah pepaya pada kerupuk mengakibatkan penurunan tingkat kesukaan panelis terhadap rasa 
kerupuk dikarenakan rasa bawang semakin berkurang. Dan pada tekstur memiliki nilai tertinggi dengan nilai ratarata $3.57 \%$ yaitu terdapat pada perlakuan ketiga P3 dapat disimpulakan bahwa semakin banyak penambahan buah pepaya pada kerupuk dapat mengakibatkan penurunan tingkat kesukaan panelis terhadap tekstur kerrupuk dikarenakan kerupuk yang dihasilkan semakin keras.

\section{B. Saran}

Perlu dikaji lebih lanjut mengenai uji higroskopisitas kerupuk yang dihasilkan dalam rangka mengetahui umur simpan produk tersebut.

\section{DAFTAR PUSTAKA}

Annas, S. M. 2016. "Pengaruh Varietas Dan Lama Simpan Terhadap Sifat Kimia Buah Pepaya (Carica papaya. L). Program Studi S1 Teknologi Hasil Pertanian Jurusan Teknologi Pertanian Universitas Semarang.

Ayustaningwarno, F. 2014. Teknologi Pangan: Teori Praktis dan Aplikasi. Graha IImu. Yogyakarta.

Amnan, F., Maryam, S., Dan Aida, S. 2019. Analisis Tingkat Kesejahteraan Ekonomi Petani Berdasarkan Pendapatan Usahatani Pepaya California (Carica Papaya L.) Di Muang Dalam Kelurahan Lempake Kecamatan Samarinda Utara. Jurusan/Program Studi Agribisnis, Fakultas Pertanian, Universitas Mulawarman. Kalimantan Timur.

Balai Pengujian Mutu Dan Sertifikasi Pangan. 2019. E Modul Metode Pengujian. Kementrian Pertanian Republik Indonesia. Bekasi.

Desi A. 2017. "Varian Ikan Nike (Awaous melanocephalus) Dan Ikan Cakalang (Katsuwonus pelamis) Terhadap Mutu Kerupuk". Program Studi Teknologi Hasil Pertanian Politeknik Gorontalo.

Direktorat Jendral Holtikultura. 2011. PDB Beberapa Komoditas Sayuran Terhadap Total PDB Sayuran Nasional Tahun 2010. Kementrian Pertanian.

Ismawati, U. 2015. Sertifikat Prima: Jaminan Mutu Produk Peranian.

Erawati, W.R. 2001. Pengaruh Bahan Pengikat, Waktu Penggorengan Dan
Daya Simpan Terhadap Sifat Fisik Dan Organoleptik Nagget Ikan Sapu-sapu (Hyposasus Pardalis). Fakultas IImu Kelautan Dan Perikanan. Institut Pertanian Bogor, Bogor.

Kemal, T. 2001. Teknologi Tepat Guna Agroinustri. Jakarta: Swadaya

Korompot, A. R., F Fatimah,. D Wuntu 2018. Kandungan Serat Kasar Dari Bakasang Ikan Tuna (Thunnus sp.). Jurnal IImiah Sains.

Koswara, S. 2009. Pengolahan Aneka Kerupuk. Ebookpangan.com

Lestari D. W. 2013. Pengaruh Subtitusi Tepung Tapioka Terhadap Tekstur Dan Nilai Organoleptik Dodol Susu. Skripsi Fakultas Peternakan, Universitas Brawijaya Malang.

Majhan A, 2016. Pembuatan Kerupuk Dari Daging Buah Naga Merah(Hylocereus costarcensis). Politeknik Negeri Samarinda.

Nadia, A., F. Herdiansyah, H. Rahmawati, Y. Setiartini, dan R. Harrysetiawan. 2014. Penentuan Kadar Air dan Kadar Abu dalam Biskuit. Jurnal Praktikum Kimia Analitik II. Fakultas IImu Tarbiyah dan Keguruan. Universitas Islam Negeri Syarif Hidayatullah. Jakarta.

Rosiani, N., Basito, dan E. Widowati. 2015. Kajian Karakteristik Sensoris Fisik Dan Kimia Kerupuk Fortifikasi Daging Lidah Buaya (Aloe Vera) Dengan Metode Pemanggangan Menggunakan Microwave. Jurnal Teknologi Pertanian.

Setyaningsih, D., A. Apriyantono, dan M. P. Sari. 2010. Analisis Sensori untuk Industri Pangan dan Agro. Institut Pertanian Bogor Press. Bogor.

Setiyorini, E. I. 2013. Pengaruh Penambahan Udang Rebon dan Jamur Tiram Terhadap Hasil Jadi Kerupuk Udang Rebon. S1 Pendidikan Kesejahteraan Keluarga, Tata Boga Fakultas Teknik Universitas Negeri Surabaya. E-Journal Boga.

Subhan. 2014. Analisis Kandungan Iodium dalam Garam Butiran Konsumsi yang Beredar di Pasaran Kota Ambon. Jurnal Fikratuna.

Sujiprihati S dan Suketi K. 2009. Budidaya Pepaya Unggul. Jakarta : Penebar Swadaya.

Sihombing, M. 2014. Kinetika Hidrolisis Pembentukan Gula Pereduksi Dengan 
Pengaruh Variasi Konsentrasi HCL dan Temperatur Hidrolisi. (Laporan Akhir). Jurusan Teknik Kimia. Politeknik Negeri Sriwijaya. Palembang.

Utami, A. P., S. Wahyuni, dan Muzuni. 2016. Analisis Penilaian Organoleptik dan Nilai Gizi Cookies Formulasi Tepung Wikau Maombo. Jurnal Sains dan Teknologi Pangan.

Wahyunintias N., Basito, Atmaka W, 2014. "Kajian Karakteristik Fisikokimia Dan Sensoris Kerupuk Berbahan Baku Tepung Terigu, Tepung Tapioka Dan Tepung Pisang Kepok Kuning". Jurnal Teknosains Pangan.

Warisno. 2003. Budidaya Tanaman Pepaya. Kanisius, Yogyakarta. 